\title{
Hypostomus chrysostiktos, a new species of armored catfish (Siluriformes: Loricariidae) from rio Paraguaçu, Bahia State, Brazil
}

\author{
José L. O. Birindelli*, Angela M. Zanata** and Flávio C. T. Lima*
}

Hypostomus chrysostiktos, a new species of armored catfish of the family Loricariidae, is described. The most remarkable characteristic of the new species, which allows its prompt diagnosis from congeners, is the high number of branched rays in the dorsal fin (10-11). In addition, the new species can be diagnosed from the remaining Loricariidae by the combination of the following characters: slightly evertible cheek plates, four branched anal-fin rays, naked abdomen, and snout almost completely plated. The characters states shared by H. chrysostiktos and the tribe Hypostomini, which indicates it as belonging to that group, are: a hatched-shaped opercle, the anterior process of the pterotic-supracleitrum passing halfway the orbit, a pointed post-cleithral process, and slightly evertible cheek plates. The description of this armored catfish provides more evidence for the high level of endemism in the ichthyofauna of rio Paraguaçu basin, a coastal river of northeastern Brazil.

Uma nova espécie de cascudo da família Loricariidae, Hypostomus chrysostiktos, é descrita. A característica mais marcante da nova espécie, que permite diagnosticá-la das congêneres, é o grande número de raios ramificados da nadadeira dorsal (10-11). A nova espécie pode ser ainda diagnosticada dos demais Loricariidae pela combinação dos seguintes caracteres: placas laterais da cabeça levemente eversíveis, quatro raios ramificados na nadadeira anal, abdômen nu, e focinho quase completamente coberto por placas. Os estados de caracteres compartilhados entre H. chrysostiktos e a tribo Hypostomini, os quais indicam que a nova espécie pertence ao grupo, são: opérculo em forma de machado, processo anterior do pterótico-supracleitro passando metade da órbita, processo pós-cleitral afilado, e placas laterais da cabeça levemente eversíveis. A descrição deste cascudo é outro exemplo que evidencia o alto grau de endemismo da ictiofauna da bacia do rio Paraguaçu, uma drenagem costeira do nordeste brasileiro.

Key words: Hypostominae, Hypostomini, Eeastern brazilian drainages.

\section{Introduction}

The armored catfish family Loricariidae, with over 690 species in 70 genera (Reis et al., 2003), is the most diverse within the order Siluriformes and is one of the largest of all fish families, distributed from Costa Rica in Central America to La Plata basin in Southern South America. The genus Hypostomus Lacepède is the most speciose within the family Loricariidae, with approximately 130 species recognized as valid, and an estimated one third more still to be described (Weber, 2003; Hollanda Carvalho \& Weber, 2004). Coupled with the elevated number of species, the considerable intraspecific variation has caused problems in delimiting species within the genus. To quote Gosline (1947: 111): "the taxonomist trying to identify a specimen of Plecostomus (= Hypostomus) will probably feel disgruntled to find himself presented with a problem rather than a name". Even though 60 years have elapsed since, that comment on Hypostomus taxonomy remains valid. More recently, the most meaningful contributions to the systematics of the genus were regional revisions, such as Boeseman (1968, 1969), Reis et al. (1990), Mazzoni et al. (1994), and Oyakawa et al. (2005), or revisions on monophyletic subunits of the genus (e.g., Armbruster, 1998a, 2003; Hollanda Carvalho \& Weber, 2004). There are still much to be clarified concerning species limits within the genus.

There have been relatively few studies addressing the relationships within Loricariidae (e.g., Howes, 1983; Schaefer, 1987; Montoya-Burgos et al., 1997, 2002; Armbruster, 2004). The most recent and detailed analysis was presented by Armbruster (2004), which proposed major rearrangements in the taxonomy of the higher taxa of the family. The most important change was the fusion of the majority of Hypostominae (sensu Isbrücker, 1980) with the Ancistrinae (sensu Isbrücker, 1980) into a single subfamily, Hypostominae. Armbruster (2004)

\footnotetext{
*Museu de Zoologia da Universidade de São Paulo, Caixa Postal 42494, 04218-970 São Paulo, SP, Brazil. jbirindelli@yahoo.com.br; fctlima@usp.br

**Departamento de Zoologia, Instituto de Biologia, Universidade Federal da Bahia, Rua Barão de Geremoabo, s/n, Ondina, 40170-290 Salvador, BA, Brazil. a_zanata@yahoo.com.br
} 
recognized five monophyletic tribes within it: Corymbophanini, Rhinelepini, Hypostomini, Pterygoplichthyni, and Ancistrini. All the former genera included in the tribe Hypostomini (Cochliodon, Aphanotorulus, Isorineloricaria, Cheirododus, Squaliforma and Watawata) were synonymized with the genus Hypostomus, which was then considered to be monophyletic, though supported by relatively few synapomorphies, none of which is exclusive. Armbruster's (2004) conclusions on Hypostomini are not, however, consensual: Montoya-Burgos et al. (2002) presented molecular evidence for a paraphyletic Hypostomus, based on which Weber (2003) recognized as valid the genera Aphanotolurus, Isorineloricaria, plus the genus Squaliforma for Hypostomus emarginatus and related species.

In the last few years, increasing colleting efforts in the rio Paraguaçu basin, a coastal drainage of eastern Brazil, have revealed a rich, endemic ichthyofauna (Higuchi et al., 1990; de Pinna, 1992; Campanario \& de Pinna, 2000; Lima \& Gerhard, 2001; Zanata \& Akama, 2004; Malabarba et al., 2004; Britto et al., 2005). To that list we add below a new armored catfish of the family Loricariidae that is also apparently endemic to the rio Paraguaçu basin.

\section{Material and Methods}

Methodology and terminology for measurements follow Boeseman (1968), Armbruster \& Page (1996), Bockmann \& Ribeiro (2003), and Hollanda Carvalho \& Weber (2004), with the inclusion of the following measurements: anal-fin spine length; anal-fin base length; body depth at dorsal-fin origin; mouth width, taken at the level of maxillary-barbels insertion; premaxillary-ramus length; and maxillary-barbel length, taken from free inner portion of barbel. Plate counts and nomenclature follow schemes of serial homology proposed by Schaefer (1997), with modifications by Oyakawa et al. (2005). The following new counts were included: paired dorsal plates between end of the dorsal-fin base and adipose-fin base; ventral plates between end of anal-fin base and lower caudal-fin spine, not including plate at base of rays. Standard length (SL) is expressed in $\mathrm{mm}$ and all other measurements are expressed as percentage of standard length, except subunits of head, which are expressed as percentage of head length. Measurements and counts were taken on the left side of the specimens, whenever possible. Osteological examination, counts of branchiostegal rays, vertebrae, and data on position of dorsal, pelvic and anal fins in relation to vertebral column were examined only in cleared and stained specimens, prepared according to the procedures of Taylor \& Van Dyke (1985). Osteological terminology follows Schaefer (1987). Illustrations were traced over high quality digital pictures taken with camera attached to a stereomicroscope Zeiss SV6. All examined specimens are alcohol preserved, except when noted with $\mathrm{c} \& s$, indicating cleared and stained specimens.

Phylogenetic analysis was performed using the character matrix published by Armbruster (2004), with the addition of the new species described herein. The matrix was edited using
MacClade version 4.06 (Maddison \& Maddison). The analysis was performed using PAUP version 4.0b10 (Swofford), using the tree bisection-reconnection in a heuristic search. Characters were ordered as indicated by Armbruster (2004).

Specimens examined belong to the following institutions: ANSP, Academy of Natural Sciences, Philadelphia; AUM, Auburn University Museum, Auburn; MCP, Museu de Ciências e Tecnologia, Porto Alegre; MNRJ, Museu Nacional, Rio de Janeiro; MZUSP, Museu de Zoologia da Universidade de São Paulo, São Paulo; UFBA, Universidade Federal da Bahia, Salvador.

\section{Hypostomus chrysostiktos, new species}

Figs. 1 and 2

Pterygoplichthys sp.: Higuchi, Britski \& Garavello, 1990: 225 [misidentification; Bahia, rio Paraguaçu at the area currently under Pedra do Cavalo dam].

Holotype. MZUSP 88157, 222.4 mm SL, Brasil, Bahia, Iaçu, rio Paraguaçu, Fazenda Santo Antonio at $10 \mathrm{~km}$ from Vila São Vicente, 12॰30'54.1'’S 39॰22'53.9'W, 134 m elevation, 7 Jun 2005; A. M. Zanata, J. L. O. Birindelli, O. T. Oyakawa, M. P. Geraldes, P. C. A. Cardoso \& P. Moura.

Paratypes. All from Brazil, Bahia, rio Paraguaçu basin: ANSP 185374, 1, 166.6 mm SL; MZUSP 88158, 3, 157.9-212.2 mm SL; collected with holotype. AUM 45646, 1, $117.0 \mathrm{~mm}$ SL; MZUSP 88159, 5, 72.7-223.5 mm SL; UFBA 02786, 5, 112.3-259.7 mm SL; Iaçu, rio Paraguaçu, Fazenda Os Touros, 1241'10.6”S 4007'4.7'W, 143 m elevation, 8 Jun 2005; A. M. Zanata et al. . MCP 41000, 1, $101.0 \mathrm{~mm}$ SL; MZUSP 91635, 3, 96.5-149.5 mm SL; Itaetê, rio Una, 1256'08'S 4103'54", 4 Dez 2005; A. M. Zanata et al. MNRJ 22780, 2, 50.4147.3 mm SL; Palmeiras, rio Santo Antônio (Bahema), 12²5'16.6”'S 412'20.9'W, 8 Nov 1999; A. Clistenes. MNRJ 22781, 1, 151.6 mm SL; Palmeiras, rio Santo Antônio (Camelo), 12²5'36.7’'S

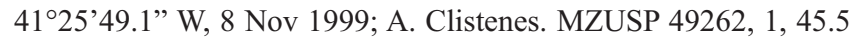
mm SL; MZUSP 84231, 3 (1 c\&s), 29.0-33.1 mm SL; Itaetê, Olho d'água do Almerindo, tributary of rio Una, Jun 1993; A. M. Zanata et al. MZUSP 88161, 2, 68.4-104.5 mm SL; UFBA 02788, 2, 79.4-93.4 $\mathrm{mm}$ SL; rio Ferro Doido at Cachoeira Domingos Lopez, rio Jacuípe basin, 11'33'32.1'S 4054'20.3'W, 662 m elevation, 11 Jun 2005; A. M. Zanata et al. MZUSP 88165, 2 ( $1 \mathrm{c} \& \mathrm{~s}), 117.5-122.7 \mathrm{~mm}$ SL; MZUSP 88617, 2 (1 c\&s), 114.0-194.8 mm SL; UFBA 02031, 3, 60.3-82.3 mm SL; UFBA 02040, 23, 78.2-163.8 mm SL; UFBA 02785, 6, 129.4-222.8 mm SL; Cachoeira, rio Paraguaçu (area currently under Pedra do Cavalo dam), 15 Oct 1980; V. Almeida et al. . MZUSP 88173, 1, 117.9 mm SL; UFBA 02039, 2, 115.2-133.4 mm SL; Lençóis, rio Santo Antônio de Licurioba, 5 Feb 2001; L. Panelli. UFBA 02030, 2, 100.4-153.9 mm SL; Cachoeira, rio Paraguaçu (area currently under Pedra do Cavalo dam), 13 Aug 1980; V. Almeida et al. UFBA 02787, 3, 211.9-223.9 mm SL; Iaçu, rio Paraguaçu, Fazenda Os Touros, 12 41'10.6'S 4007'4.7'W, 143 m elevation, 9 Jun 2005; A. M. Zanata et al.

Diagnosis. Hypostomus chrysostiktos is readily distinguished from most loricariids, with the exception of Megalancistrus, a few species of Chaetostoma, and some species of Pterygoplichthys and Delturus, by the high number of dorsal-fin branched rays (10-11). It can also be distinguished by having slightly evertible cheek plates ( $v s$. fully evertible cheek 
plates of Chaetostoma, Megalancistrus, and most other Ancistrini and Pterygoplichthyini taxa; or no evertible cheek plates in Delturinae, Neoplecostominae, Hypoptopomatinae, Loricariinae, Corymbophanini and Rhinelepini). It can be further distinguished from Delturus by having four branched anal-fin rays ( $v s$. five or six branched anal-fin rays). In addition, the new species differs from several loricariids by having naked abdomen (vs. plated in e.g. Pterygoplichthys), snout almost completely plated leaving just a small naked area on its tip (vs. snout completely naked in e.g. Chaetostoma). See Discussion for additional notes on its diagnosis.

Description. Standard length of examined specimens 29.0 to $259.7 \mathrm{~mm}$. Counts and measurements of holotype and paratypes in Tables 1 and 2. Dorsal, lateral, and ventral views of head and body in Figure 1. Dorsal profile of body convex from snout tip to dorsal-fin origin, and straight from this point to middle of caudal peduncle. Ventral profile of body straight from snout to caudal-fin base. Body relatively depressed; greatest body width at cleithral region, progressively tapering posteriorly from cleithrum. Greatest body depth at dorsal-fin origin, gradually tapering to caudal peduncle. Caudal peduncle robust and roughly trapezoid in cross-section; somewhat flattened on ventral portion.

Head somewhat depressed, wide, and round anteriorly. Head without crests. Posterior border of supraoccipital straight to somewhat irregular in form, without distinct posteriorly directed expansion. One plate bordering posterior margin of supraoccipital bone. Interorbital region straight, with lateral margins elevated. Eyes relatively small. Dorsal flap of iris present. Mouth distinctly wide; roof with relatively small median buccal papilla. Lips rounded, of moderate size, occupying approximately two-thirds of ventral surface of head, with fringed edges. Inner surfaces of lips covered by papillae, except for smooth region just behind toothed portions of dentaries; smooth region wider posterior to symphysial region. Anteriormost papillae of inner surface of lower lip roundish and relatively large, followed by patch of smaller and closely positioned papillae; anteriormost papillae in inner surface of upper lip roundish and small, followed by patch of larger and more elongated papillae. Teeth long and bicuspid; larger cusp approximately 1.5 to 2.0 times length of outer cusp and curved inward, similar to Hypostomus auroguttatus (Muller \& Weber, 1992: fig. 2e). Contralateral premaxillary teeth forming relatively straight line or slightly concave arch; contralateral dentaries forming relatively wide angle and dentary teeth forming concave arch facing mouth cavity. Maxillary barbel short, usually shorter than orbital diameter.

Dorsal-fin origin situated on vertical anterior to pelvic-fin origin and approximately on midlenght of pectoral-fin spine. Tips of first and last basal radials of dorsal fin lying above neural spines of vertebrae seven and 19, respectively. Dorsal fin large; tips of adpressed last rays almost reaching to slightly surpassing posterior border of preadipose plate. Margin of dorsal fin slightly convex. Adipose-fin spine narrow, usually straight or slightly curved ventrally. Pectoral fin of moderate size with posterior margin straight to slightly concave. Degree of overlaping of posterior tip of adpressed pectoral fin over pelvic fin ontogenetically variable; tip of pectoral reaching middle of pelvic fins in smaller and median-sized specimens, and reaching posterior third of pelvic-fin spine in largest individuals. Pectoral fins inserted about same plane as pelvic fins and pectoral-fin spine resting on top of pelvic-fin when adpressed. Pelvic fin of moderate size, with posterior margins rounded in smaller and straight in larger specimens. Tip of pelvic fin reaching origin of anal-fin rays. Plate of first proximal radial of anal fin covered by skin in all specimens examined. Tips of first and last basal radials of anal fin lying below hemal spines of vertebrae 16-18, respectively. Caudalfin margin concave, lower spine longer than upper. Thirty vertebrae, four branchiostegal rays.

Body entirely covered by plates, except for ventral surface from mouth to anus and areas around dorsal, pectoral, pelvic, and anal-fin insertions. Cheeks, snout, and rostrum completely plated, except for naked area on snout tip that continues ventrally to margin of upper lip, and small areas around nares. Ornamentation of pterotic-supracleithrum usually similar to remaining surface of head and with odontodes densely distributed, arranged in well-defined rows, diverging posteriorly in larger specimens. Plates over opercle weakly armed, varying from covered with relatively small odontodes similar in size

Table 1. Morphometric data for Hypostomus chrysostiktos. Letters in parenthesis correspond to Boeseman (1968: fig. 5) measurements.

\begin{tabular}{lccccc}
\hline & Holotype & $\mathrm{N}$ & Range & Mean & SD \\
\hline Total length in mm (C) & 299.3 & 31 & $50.4-315.3$ \\
Standard length in mm (A) & 224.4 & 63 & $29.0-259.7$ \\
& \multicolumn{5}{c}{ Percents of standard length } \\
Predorsal length (D) & 35.7 & 62 & $35.7-43.0$ & 39.0 & 1.2 \\
Preanal length & 65.7 & 62 & $65.7-70.4$ & 68.0 & 1.0 \\
Head length (E) & 29.4 & 62 & $28.1-37.4$ & 31.9 & 1.7 \\
Interdorsal length (M) & 15.4 & 61 & $12.4-17.4$ & 14.9 & 1.3 \\
Thoracic length (N) & 22.5 & 62 & $20.2-25.2$ & 23.4 & 1.2 \\
Abdominal length (P) & 24.9 & 62 & $21.2-27.8$ & 25.5 & 1.1 \\
Caudal peduncle length (R) & 29.9 & 62 & $26.2-33.2$ & 29.1 & 1.1 \\
Caudal peduncle depth (S) & 9.3 & 62 & $9.2-10.7$ & 9.9 & 0.4 \\
Dorsal-fin spine length (K) & 28.4 & 49 & $26.3-34.0$ & 30.2 & 1.8 \\
Folded dorsal-fin length & 43.7 & 56 & $37.8-48.9$ & 44.2 & 1.8 \\
Dorsal-fin base length (L) & 29.5 & 62 & $27.7-35.7$ & 30.1 & 1.3 \\
Anal-fin spine length & 12.7 & 53 & $9.3-14.7$ & 12.3 & 1.1 \\
Anal-fin base length & 3.3 & 62 & $2.3-4.7$ & 3.4 & 0.5 \\
Pectoral-fin spine length (O) & 35.2 & 55 & $29.1-36.4$ & 32.6 & 1.8 \\
Pelvic-fin spine length (Q) & 22.4 & 60 & $22.4-27.9$ & 25.2 & 1.3 \\
Upper caudal-fin ray length & 28.4 & 26 & $25.3-33.6$ & 28.9 & 2.2 \\
Lower caudal-fin ray length & 34.1 & 29 & $30.4-39.1$ & 33.9 & 2.3 \\
Adipose-fin spine length & 7.8 & 61 & $6.4-9.2$ & 7.9 & 0.8 \\
Cleithral width (F) & 27.9 & 62 & $27.3-33.6$ & 29.9 & 1.0 \\
Body depth & 18.0 & 62 & $16.6-22.8$ & 19.4 & 1.5 \\
& \multicolumn{5}{c}{ Percents of head length } \\
Head depth (G) & 55.1 & 62 & $47.2-62.3$ & 55.3 & 3.6 \\
Snout length (H) & 67.2 & 62 & $56.8-71.2$ & 64.3 & 3.2 \\
Snout-opercle distance & 81.0 & 62 & $68.9-87.2$ & 77.3 & 3.9 \\
Interorbital width (J) & 34.3 & 62 & $30.9-39.7$ & 34.8 & 1.8 \\
Orbital diameter (I) & 11.4 & 62 & $9.6-15.5$ & 12.7 & 1.5 \\
Mouth width & 64.8 & 61 & $52.4-68.8$ & 60.4 & 3.7 \\
Mandibular ramus length & 20.8 & 62 & $15.6-22.8$ & 19.8 & 1.5 \\
Premaxillar ramus length & 20.6 & 62 & $15.0-22.6$ & 19.1 & 1.5 \\
Maxillary barbells length & 6.8 & 57 & $2.5-9.5$ & 6.6 & 1.7 \\
\hline
\end{tabular}


with those in nearby areas to posterior portion of opercle with slightly more elongated odontodes (up to 22). Posterior portion of preopercle surface varying from having small odontodes to up to twenty slightly elongate odontodes. Cheek plates slightly evertible. Median series of plates bearing lateral-line canal. Dorsal series of plates starting posteriorly, at vertical through dorsal-fin origin. Ventral series of plates usually starting at midlength of pelvic-fin base. Dorsalmost plates between end of dorsal-fin base and adipose-fin spine flattened. One preadipose plate. Five rows of plates on the caudal peduncle.

Plates on dorsal and lateral portion of body relatively smooth in all specimens examined. Defined keels present only in mid-ventral series of plates, more developed on first five plates. Weakly developed crest in mid-dorsal series of plates of some individuals. Plates situated on dorsal and lateral portion of body covered with minute odontodes, clearly orga-

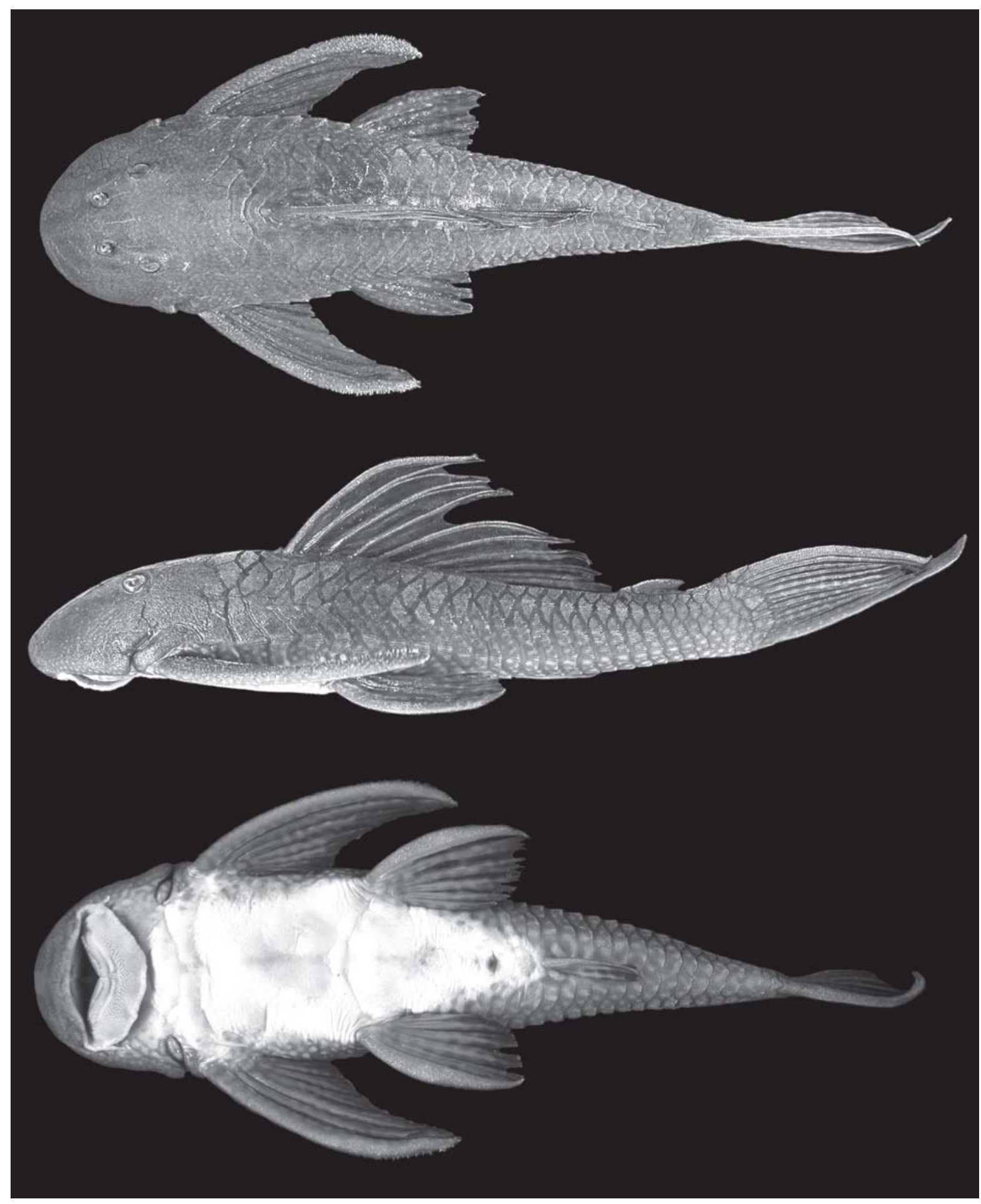

Fig. 1. Dorsal, lateral, and ventral views of Hypostomus chrysostiktos, MZUSP 88157, holotype, 222.4 mm SL. 
nized in rows diverging posteriorly; odontodes usually more developed on borders of plates of mid-dorsal and midventral series. All fin rays covered by small odontodes, more conspicuous in dorsal-fin rays and adipose spine. Dorsal and lateral surfaces of anterior portion of pectoral fin spine covered with relatively small odontodes, increasing in size and curvature towards posterior portion of pectoral-fin spine; odontodes more developed in specimens of $180.0 \mathrm{~mm} \mathrm{SL}$ or larger. Dorsal surface of branched pectoral-fin rays with small odontodes along their entire lengths; odontodes more conspicuous on larger individuals. Pelvic-fin spine and dorsal surface of all branched rays covered with small odontodes along their entire length. Caudal-fin rays covered with odontodes, more evident on unbranched rays.

Color in alcohol. Overall ground color of dorsal and lateral surface of body brownish. Body covered with small roundish clear spots. Light brown spots on head and dorsal portion of trunk. Spots usually more evident and larger on lower lateral portion of body. Spots on dorsal portion of head relatively smaller than those of trunk, less interspaced and decreasing in size towards snout. Trunk and fins covered with comparatively larger spots; some specimens around $90 \mathrm{~mm}$ SL with longitudinally-aligned spots. Naked ventral surface of head and body (including lips) pale to yellowish from area behind lower lip to area close to anal-fin insertion. Naked area of snout and upper lip covered with small clear spots (more evident on UFBA 02788 specimens). Ventrolateral margins of head and body with dark coloration and large pale spots and vermiculations at boundaries between plated and naked areas in most specimens examined; specimens around $100 \mathrm{~mm} \mathrm{SL}$ with dark vermiculations across coracoid region. Ventral portion of caudal peduncle usually dark brown, with clear spots and/or vermiculations sparsely distributed.
Overall ground coloration of all fins dark brown with spots scattered distributed over spines, rays and inter-radials membranes. Spots over fins usually similar in size to those distributed over trunk. Caudal-fin spots usually paler than those of remaining fins. Spots of paired fins clearer from ventral view. Some specimens, often those with very dark overall pigmentation, with spotted pattern described above less visible; spots nearly completely absent in some individuals.

Color in life. Description based on field observations of several specimens by JLOB and AMZ, and on pictures of living specimens (see Fig. 2). Ground color brown with bright yellow spots, much more evident than in preserved specimens. Ventral surface of body yellowish. Yellow spots on fins more conspicuous over rays.

Distribution. Only known from rio Paraguaçu basin, an independent coastal drainage in northeastern Brazil, where it is widespread (Fig. 3).

Etymology. From the greek chrysos, after gold, and stiktus, after spotted, in allusion to the bright yellow spots present in living specimens. An adjective.

Ecological notes. Hypostomus chrysostiktos was collected in dark water stretches of the rio Paraguaçu and its tributaries, with rocky bottom, at altitudes ranging from 50 to 662 meters above sea level.

Phylogenetic relationships. The 215 characters previously defined by Armbruster (2004) for loricariids and outgroups were coded for $H$. chrysostiktos (Table 3). Hypostomus chrysostiktos was then added to Armbruster's (2004) matrix. The resulting phylogenetic hypothesis recovered $H$.

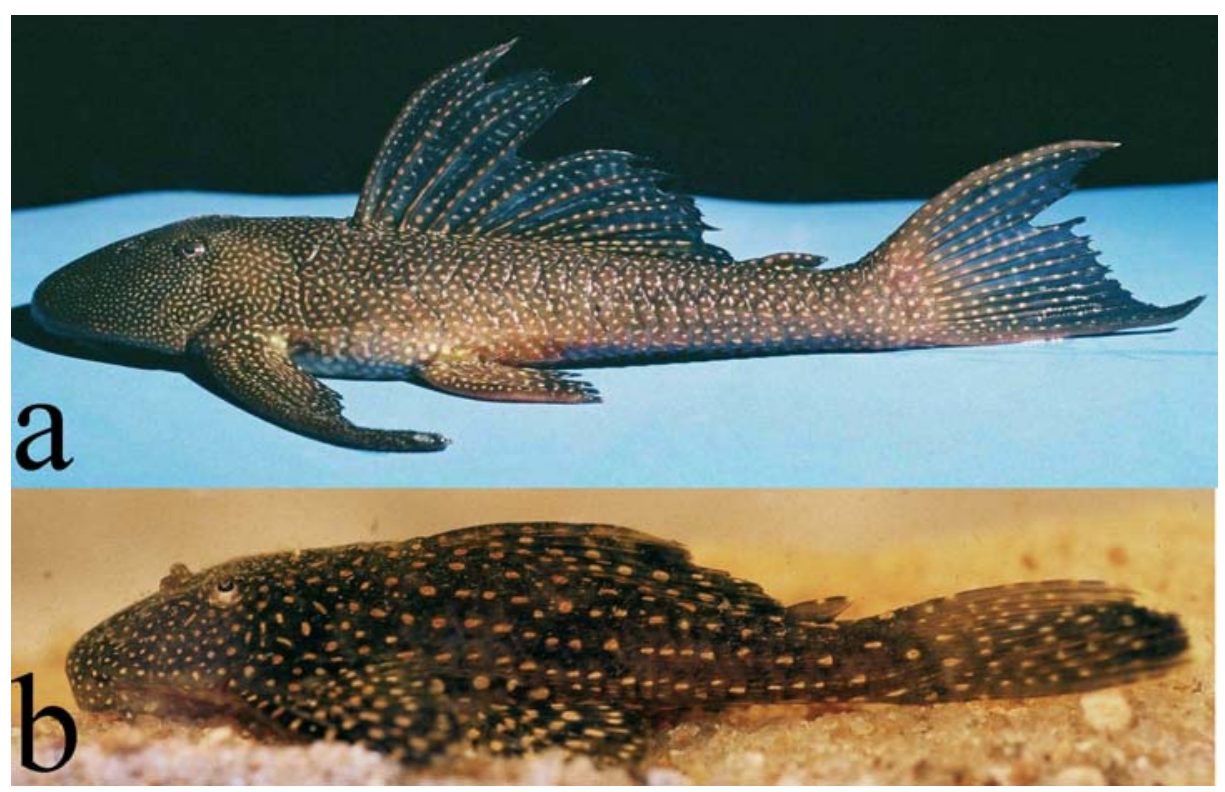

Fig. 2. Lateral view of Hypostomus chrysostiktos, photographed alive. a, MZUSP 88157, holotype, $222.4 \mathrm{~mm}$ SL; b, MZUSP $88161,104.5 \mathrm{~mm}$ SL. 
Table 2. Meristic data for Hypostomus chrysostiktos.

\begin{tabular}{lcc}
\hline & Holotype & Range \\
\hline Dorsal plates & 24 & $22(2) 23(34) 24(20) 25(1)$ \\
Mid-dorsal plates & 26 & $25(7) 26(41) 27(10)$ \\
Median plates & 28 & $27(1) 28(40) 29(1)$ \\
Mid-ventral plates & 27 & $26(1) 27(29) 28(33)$ \\
Ventral plates & 23 & $20(1) 21(9) 22(21) 23(31) 24(1)$ \\
Predorsal plates & 3 & $3(62) 4(1)$ \\
Dorsal pl. below dorsal-fin base & 10 & $10(34) 11(21) 12(1)$ \\
Ventral pl. between anal and & 13 & $11(3) 12(14) 13(46)$ \\
$\quad$ caudal fins & 5 & $3(1) 4(32) 5(29)$ \\
Dorsal to adipose fin plates & 10 & $10(62) 11(1)$ \\
Dorsal-fin branched rays & 6 & $6(63)$ \\
Pectoral-fin branched rays & 5 & $5(63)$ \\
Pelvic-fin branched rays & 4 & $4(63)$ \\
Anal-fin branched rays & 13 & $13(7) 14(49) 15(2)$ \\
Caudal-fin branched rays & 32 & $31-74$ \\
Teeth on left premaxilla & 35 & $35-71$ \\
Teeth on left dentary & &
\end{tabular}

chrysostiktos as the sister group of a clade composed by $H$. emarginatus group plus $H$. commersoni and, consequently, within the Hypostomini tribe (sensu Armbruster, 2004). Armbruster (2004: 51) found two well-corroborated monophyletic entities within the tribe Hypostomini, the $H$. emarginatus group (including Aphanotolurus and Isorineloricaria) and the H. cochliodon group. Nevertheless, "there are no general trends in the relationships of the remainder of the species" (Armbruster, 2004: 51). Hypostomus chrysostiktos does not have the diagnostic characters for any of the two afore-mentioned groups (see Armbruster, 2004: 51).

Hypostomus chrysostiktos is included in the subfamily Hypostominae by possessing the following characters: a long acessory process on the first ceratohyal (character 7: state 2 of Armbruster, 2004), the lower lobe of hypural plate longer than the upper (123: 1), a V-shaped spinelet (148: 0), and a posteroventral ridge on the basipterygium (173: 1). Hypostomus chrysostiktos belongs to the clade including Hypostomini, Pterygoplichthyni, and Ancistrini by the presence of eight derived characters (e.g., anterior process of pterotic-supracleitrum separated mesially from main body, connected by a strut (111:

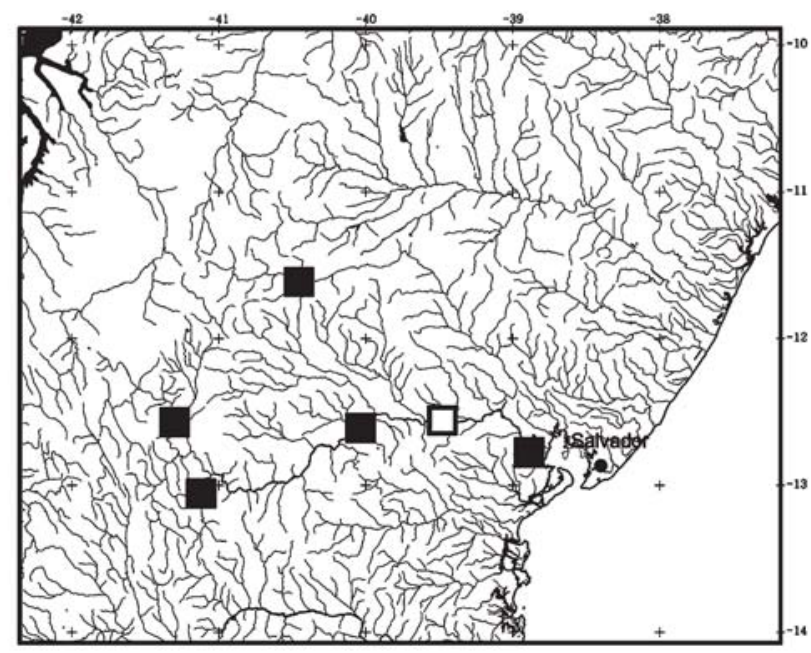

Fig. 3. Rio Paraguaçu basin and adjoining area in Northeastern Brazil, showing geographic distribution of Hypostomus chrysostiktos (type-locality represented by open square).
1); four branched anal-fin rays (150:2), and slightly evertible cheek plates (184: 1). Finally, H. chrysostiktos shares with the members of the currently defined Hypostomini the presence of a hatched-shape opercle (78:1), the anterior process of the pterotic-supracleitrum passing halfway through the orbit (112: $1)$, and a pointed post-cleithral process (156: 1).

\section{Discussion}

The most remarkable characteristic of Hypostomus chrysostiktos, unique within the Hypostomini, is the high number of branched dorsal-fin rays (10-11), whereas in most loricariids there are seven branched rays. The exceptions are Farlowella, which possess only six branched rays, and within Hypostominae, three groups that possesses more than seven branched rays in dorsal fin: Pterygoplichthys, with ten to thirteen, the Chaetostoma group (including Dolichancistrus, Leptoancistrus and Cordylancistrus, with eight, and a few species of Chaetostoma, with nine or ten), and the Acanthicus group (including Acanthicus, Leporacanthicus and Pseudacanthicus, with eight, and Megalancistrus, with ten branched dorsal-fin rays). The relatively basal Loricariidae genus Delturus possess nine or ten branched dorsal-fin rays. Since these taxa are not closely related (Regan, 1904; Gosline, 1947, Armbruster, 2004), an increase to eight or more rays has occurred independently several times within Loricariidae. In addition to the high number of dorsal-fin rays, $H$. chrysostiktos possess at least two other derived characters: presence of a lateral process of ventral process of Weberian-complex centrum (136: 1) (shared with Hypostomus cochliodon, H. hondae, and the Panaque dentex group), and a well-developed laminar flange on the first epibranchial (Fig. 4). The presence and the degree of development of an accessory flange on the first epibranchial in loricariids were discussed by Schaefer (1987: 14, fig. 8b; 1997: 27, fig. 14a) and Armbruster (2004: character 14). The larger cleared and stained specimen of $H$. chrysostiktos examined (MZUSP 88617, $114.0 \mathrm{~mm} \mathrm{SL}$ ) possess a well-developed laminar flange on the first epibranchial, a condition apparently unusual in the Hypostominae (cf. Schaefer, 1987: 14). However, smaller specimens of H. chrysostiktos (MZUSP 84231, $32 \mathrm{~mm}$ SL; MZUSP 88161, $71 \mathrm{~mm} \mathrm{SL}$ ) possess a less developed flange. A detailed study of the variation of the development of the first epibranchial accessory flange in Hypostominae is necessary to achieve a proper assessment of this character.

The unique previous reference to Hypostomus chrysostiktos in the literature was as an unidentified species of Pterygoplichthys (Higuchi et al., 1990: 225). Hypostomus chrysostiktos lacks one of the three synapomorphies proposed for Pterygoplichthys (including Liposarcus and

Table 3. Character states for 215 characters of Hypostomus chrysostiktos. Characters based on Armbruster (2004).

$0020002201-0001001101-0000021011-0011010000-00 ? 1000000-$ $1220002000-0001010000-000 ? 000101-1110 ? 00 ? 01-1011001002-$ $0000100001-1100000010-2010000000-0000010120-0100100002-$ $00000 ? 0100-0111001100-1010200000-0101000001-1010131000-$ $100000000 ?-? ? 000$ 
Glyptoperichthys) by Armbruster (2004: 53), i.e., the diminutive or absent interhyal located posteriorly. The two remaining synapomorphies of Pterygoplichthys, which are shared with $H$. chrysostiktos (eight or more dorsal-fin rays and 8-11 postdorsal vertebrae) are both linked to the extension of the dorsal fin. Hypostomus chrysostiktos also lacks the unique diagnostic characteristic for the tribe Pterygoplichthini (Armbruster, 2004: 61), namely the presence of an enlarged stomach that is attached to the dorsal abdominal wall by a connective tissue sheet (see also Armbruster, 1998b), and at least one of the synapomorphies uniting Pterygoplichthyini to Ancistrini, the fully evertible cheek plates. Moreover, $H$. chrysostiktos lacks some typical external features of Pterygoplichthys species, such as an abdomen fully plated, presence of an elevated supraoccipital process and predorsal plates, and keeled lateral plates (see Weber, 1992; Page et al., 1996; Armbruster \& Page, 2006). As noticed above, the position of H. chrysostiktos within the Hypostomini is corroborated in our analyses by several character states, and consequently we see no reason to consider it as closely related to the Pterygoplichthyini.

Three other species of Hypostomus were described from coastal river basins of Bahia State, namely Hypostomus unae (Steindachner, 1878), from rio Una, a small coastal river from southern Bahia, Hypostomus brevicauda (Günther, 1864), and H. wuchereri (Günther, 1864), both bearing only the vague type-locality "Bahia". The latter two species were described from material sent to the BMNH by Otho Wucherer, who very probably collected the specimens in coastal river basins southern from Salvador (the capital of Bahia state), as localities of reptiles collected by him as Canavieiras, Nazaré, and Ilhéus suggest (Günther, 1861, 1863; Wucherer, 1861a, 1861b, 1863a, 1863b). All these three aforementioned species have only seven branched dorsal-fin rays and dark blotches either over the fins (Hypostomus brevicauda) or over the whole body (H. unae and H. wuchereri) (Günther, 1864; Steindachner, 1878; see also photographs of type specimens available at All Catfish Species Inventory website: http://silurus.acnastsci.org). We have examined several unidentified Hypostomus specimens from coastal river drainages of Bahia, including the rio Una, the type-locality of $H$. unae, and specimens of Hypostomus from the rio Paraguaçu ba-

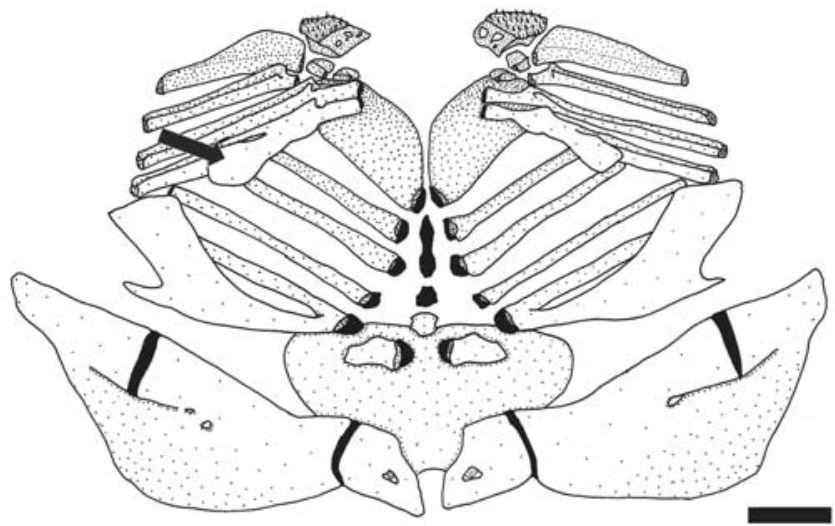

Fig. 4. Hyobranchial arch of Hypostomus chrysostiktos, showing accessory flange on the first epibranchial (arrow) $\mathrm{Bar}=1 \mathrm{~mm}$. sin, that possess seven branched dorsal-fin rays and dark blotches over the body, and which might represent some of the nominal species known from the area. Clarification of the taxonomical status of $H$. brevicauda, H. unae, and $H$. wuchereri is, however, beyond the scope of the present paper and we therefore refrain from additional remarks on the remaining Hypostomus species from coastal river basins of Bahia except from noticing that they are clearly distinct from $H$. chrysostiktos.

Comparative material. Ancistrus sp.: MZUSP 63937 (16, 2 c\&s); Delturus carinotus: MZUSP 73156 (1 c\&s); Harttia cf. punctata: MZUSP 40825 (1 c\&s); Hemipsilichthys mutuca: MZUSP 51071 (189, 2 c\&s); Hypostomus albopunctatus: MZUSP 87176 (2); MZUSP 53346 (18); H. ancistroides: MZUSP 39882 (45, 2 c\&s); H. cochliodon: MZUSP 60009 (17, 2 c\&s); H. commersoni: MZUSP 23629 (1); H. emarginatus: MZUSP 34551 (7, 2 c\&s); MZUSP 87045 (9); Hypostomus sp. (Jequitinhonha): MZUSP 86011 (16), MZUSP 5142 (3); Hypostomus sp. (Una): MCP 18064 (3); Hypostomus sp. (Itapicuru): MZUSP 90869 (8); Hypostomus sp. (Paraguaçu): MZUSP 90870 (13); Kronichthys subteres: MZUSP 71864 (10, 2 c\&s); Megalancistrus parananus: MZUSP 24435 (7, 1 c\&s); Neoplecostomus microps: MZUSP 44549 (60, 2 c\&s); Otocinclus vittatus: UFRJ 4659 (2); Pareiorhina rudolphi: MZUSP 51630 (4 c\&s); Pterygoplichthys anisitsi: MZUSP 52522 (1); P. etentaculatus: MZUSP 54759 (4); MZUSP 57555 (3); P. gibbiceps: MZUSP 7361 (1); P. joselimaianus: MZUSP 89084 (1); MZUSP 52121 (1); $P$. lituratus: MZUSP 28359 (1); P. pardalis: MZUSP 6066 (1); MZUSP 6488 (4); MZUSP 26772 (3, 1 c\&s); P. parnaibae: MZUSP 74395 (1); P. punctatus: MZUSP 24053 (1); MZUSP 6341 (3); MZUSP 13561 (1); Rineloricaria sp.: MZUSP 23748 (17, 1 c\&s).

\section{Acknowledgements}

The manuscript benefited from comments and suggestions of Jonathan W. Armbruster, Osvaldo T. Oyakawa, Heraldo A. Britski, and Naércio A. Menezes. The authors were funded by FAPESP (03/09304-3 - JLOB and 01/14449-FCTL) and CNPq (309840/2003-1 -AMZ). Recent material was gathered through fieldwork funded by All Catfish Species Inventory (NSF DEB0315963), during Expedition to Paraguaçu and Itapicurú rivers (EPI), in July 2005. We thank Osvaldo T. Oyakawa, Marcos P. Geraldes, Priscila C. A. Cardoso, and Perimar Moura for help in the field. Partial support of publication costs was provided by the All Catfish Species Inventory (NSF DEB 0315963).

\section{Literature Cited}

Armbruster, J. W. 1998a. Review of the loricariid catfish genus Aphanotorulus and redescription of A. unicolor (Teleostei: Siluriformes). Ichthyological Exploration of Freshwaters, 8: 253-262.

Armbuster, J. W. 1998b. Modifications of the digestive tract for holding air in loricariid and scoloplacid catfishes. Copeia, 1998(3): 663-675.

Armbruster, J. W. 2003. The species of the Hypostomus cochliodon group (Siluriformes: Loricariidae). Zootaxa, 249: 1-60.

Armbruster, J. W. 2004. Phylogenetic relationships of the suckermouth armoured catfishes (Loricariidae) with emphasis on the Hypostominae and the Ancistrinae. Zoological Journal of the Linnean Society, 141: 1-80.

Armbruster, J. W. \& L. Page. 1996. Redescription of Aphanotoru- 
lus (Teleostei: Loricariidae) with description of one new species, A. ammophilus, from the Río Orinoco Basin. Copeia, 1996(2): 379-389.

Armbruster, J. W. \& L. Page. 2006. Redescription of Pterygoplichthys punctatus and description of a new species of Pterygoplichthys (Siluriformes: Loricariidae). Neotropical Ichthyology, 4(4): 401-409.

Bockmann, F. A. \& A. C. Ribeiro. 2003. Description of a new suckermouth armored catfish of the genus Pareiorhina (Siluriformes: Loricariidae) from southeastern Brazil. Ichthyological Explorations of Freshwaters, 14(3): 231-242.

Boeseman, M. 1968. The genus Hypostomus Lacépède, 1803, and its Surinam representatives (Siluriformes, Loricariidae). Zoologische Verhandelingen, 99: 1-89.

Boeseman, M. 1969. Additional new species of Hypostomus Lacépède, 1803, from Suriname; with remarks on the apparent "gymnorhynchus-complex" (Siluriformes, Loricariidae). Beaufortia, 215(16): 119-136.

Britto, M., F. C. T. Lima \& A. C. A. Santos. 2005. A new Aspidoras (Siluriformes: Callichthyidae) from rio Paraguaçu basin, Chapada Diamantina, Bahia, Brazil. Neotropical Ichthyology, 3(4): 473-479.

Campanário, C. M. \& M. C. C. de Pinna. 2000. A new species of the primitive trichomycterid subfamily Copionodontinae from northeastern Brazil (Teleostei: Trichomycteridae). Ichthyological Exploration of Freshwaters, 11: 369-375.

Gosline, W. 1947. Catálogo dos nematognathos de água-doce da América do Sul e Central. Boletim Museu Nacional do Rio de Janeiro, (n. s.), Zoologia, 33: 1-138.

Günther, A. 1861. Account of the reptiles sent by Dr. Wucherer from Bahia. Proceedings of the Zoological Society of London, 1861: $12-18$

Günther, A.1863. Addition to Dr. Wucherer's article on the ophidians of Bahia. Proceedings of the Zoological Society of London, 1863: 56-58.

Günther, A. 1864. Catalogue of the fishes in the British Museum. Vol. 5. Catalogue of the Physostomi, containing the families Siluridae, Characinidae, Haplochitonidae, Sternoptychidae, Scopelidae, Stomiatidae in the collection od the British Museum. London, Taylor and Francis, xxii $+455 \mathrm{p}$.

Higuchi, H., H. A. Britski \& J. C. Garavello. 1990. Kalyptodoras bahiensis, a new genus and species of thorny catfish from northeastern Brazil (Siluriformes: Doradidae). Ichthyological Exploration of Freshwaters, 1(3): 219-225.

Hollanda Carvalho, P. \& C. Weber. 2004. Five new species of the Hypostomus cochliodon group (Siluriformes: Loricariidae) from the middle and lower Amazon System. Revue Suisse de Zoologie, 111(4): 953-978.

Howes, G. J. 1983. The cranial muscles of loricarioid catfishes, their homologies and value as taxonomic characters (Teleostei: Siluroidei). Bulletin of the British Museum (Natural History), Zoological Series, 45: 309-345.

Isbrücker, I. J. H. 1980. Classification and catalogue of the mailed Loricariidae (Pisces, Siluriformes). Verslagen en Technische Gegevens, Universiteit van Amsterdan, 22: 1-181.

Lima, F. C. T. \& P. Gerhard. 2001. A new Hyphessobrycon (Characiformes: Characidae) from Chapada Diamantina, Bahia, Brazil, with notes on its natural history. Ichthyological Exploration of Freshwaters, 12: 105-114.

Malabarba, L. R., F. C. T. Lima \& S. H. Weitzmann. 2004. A new species of Kolpotocheirodon (Teleostei: Characidae: Compsurini) from Bahia, northeastern Brazil, with a new diagnosis of the genus. Proceedings of the Biological Society of Washington, 117: 317-329.

Mazzoni, R., U. Caramaschi \& C. Weber. 1994. Taxonomical revision of the species of Hypostomus Lacépède, 1803 (Siluriformes, Loricariidae) from lower rio Paraíba do Sul, State of Rio de Janeiro, Brazil. Revue Susse de Zoologie, 101(1): 3-18.
Montoya-Burgos, J. I., S. Muller, C. Weber \& J. Pawlowski. 1997. Phylogenetic relationships between Hypostominae and Ancistrinae (Siluroidei: Loricariidae): first results from mitochondrial $12 \mathrm{~S}$ and 16S rRNA gene sequences. Revue Suisse de Zoologie, 104: 185-198.

Montoya-Burgos, J.I., C. Weber \& P.-Y. Le Bail. 2002. Phylogenetic relationships within Hypostomus (Siluriformes: Loricariidae) and related genera based on mitochondrial D-loop sequences. Revue Suisse de Zoologie, 109(2): 369-382.

Muller, S. \& C. Weber. 1992. Les dents de sous-familles Hypostominae et Ancistrinae (Pisces, Siluriformes, Loricariidae) et leur valeur taxonomique. Revue Suisse de Zoologie, 99(4): 747-754.

Oyakawa, O. T., A. Akama \& A. M. Zanata. 2005. Review of the genus Hypostomus Lacépède, 1803 from rio Ribeira de Iguape basin, with description of a new species (Pisces, Siluriformes, Loricariidae). Zootaxa, 921: 1-27.

Page, L. M., J. W. Armbruster \& M. H. Sabaj. 1996. Redescription of Glyptoperichthys scrophus, a loricariid catfish from Peru. Ichthyological Exploration of Freshwaters, 7(2): 185-191.

Pinna, M. C. C. 1992. A new subfamily of Trichomycteridae (Teleostei, Siluriformes), lower loricarioid relationships and a discussion on the impact of additional taxa for phylogenetic analisys. Zoological Journal of the Linnean Society, 106: 175-229.

Regan, C. T. 1904. Amonograph of the fishes of the family Loricariidae. Transactions of the Zoological Society of London, 17: 191-168.

Reis, R. E, S. O. Kullander \& C. F. Ferraris Jr. 2003. Family Loricariidae. Pp. 318. In: Reis, R. E, S. O. Kullander \& C. F. Ferraris Jr. (Eds.). Check List of the Freshwater Fishes of South and Central America. Porto Alegre, Edipucrs, 729p.

Reis, R. E., C. Weber \& L. R. Malabarba. 1990. Review of the genus Hypostomus Lacépède, 1803 from southern Brazil, with descriptions of three new species (Pisces, Siluriformes, Loricariidae). Revue Suisse de Zoologie, 97(3): 729-766.

Schaefer, S. A. 1987. Osteology of Hypostomus plecostomus (Linnaeus) with phylogenetic analysis of the loricariid subfamilies (Pisces: Siluroidei). Contributions in Sciences, Natural History Museum of Los Angeles County, 394: 1-31.

Schaefer, S. A. 1997. The Neotropical cascudinhos: systematics and biogeography of the Otocinclus catfishes (Siluriformes, Loricariidae). Proceedings of the Academy of Natural Sciences of Philadelphia, 148, 1-120.

Steindachner, F. 1878. Ichthyologische Beiträge. VI. Sitzungsber. Akad. Wiss. Wien, 77: 379-392.

Taylor, W. R. \& G. C. Van Dyke. 1985. Revised procedures for staining and clearing small fishes and other vertebrates for bone and cartilage study. Cybium, 9: 107-119.

Weber, C. 1992. Révision du genre Pterygoplichthys sensu lato (Pisces, Siluriformes, Loricariidae). Revue Suisse de Zoologie, 98: 637-643.

Weber, C. 2003. Subfamily Hypostominae. Pp. 351-372. In: Reis, R. E, S. O. Kullander \& C. F. Ferraris Jr. (Eds.). Check List of the Freshwater Fishes of South and Central America. Porto Alegre, Edipucrs, 729p.

Wucherer, O. 1861a. On the ophidians of the Province of Bahia, Brazil. Proceedings of the Zoological Society of London, 1861: 113-117.

Wucherer, O. 1861b. Description of a new species of Elapomorphus from Brazil. Proceedings of the Zoological Society of London, 1861: 325-326.

Wucherer, O. 1863a. On the species of Craspedocephalus which occur in the Province of Bahia. Proceedings of the Zoological Society of London, 1863: 51-54.

Wucherer, O. 1863b. On the ophidians of the Province of Bahia, Brazil. Proceedings of the Zoological Society of London, 1863: 55-56.

Zanata, A. M. \& A. Akama. 2004. Myxiops aphos, new characid genus and species (Characiformes: Characidae) from rio Lençóis, Bahia, Brazil. Neotropical Ichthyology, 2: 45-54.

Submitted December 2006 Accepted April 2007 